serveas an index during the course of his experiment-- one violin being fixed and the other moving in a grooved sliding rest. The second string was then vibrated in a uniform manner, which produced an oscillatory motion, which was heard on the corresponding string of the other violin. The paper on the string showed the vibration at a distance, and the violins were separated from each other until the agitation of the paper ceased. This point was marked as the limit of the vibrations and marked 100 , the intermediate portion being marked off to represent the one thousandth part of the distance.

Experiments made at noon with this instrument, and of en repeated, indicated the same distance within a few thousandths. The whole extent of the scale was seven feet, and this distance was the limit of the greatest propagation of sound under the influence of light in the apparatus. Parolette further states that experiments in darkness gave, as a result, a mean temperature of 0.98 , and that the mean difference of this propogation at noon and midnight was two degrees on the scale. In conclusion, Parolette tries to explain the results arrived at by stating that during the day, the atmosphere is more nearly saturated with oxygen than in the night, but he says it remains to be proved that this excess is sufficient to cause such a difference in the propagation of sound cluring the two periods. and adds, "rather, may not light be the true cause of this increased propaga'ion in oxygen and nitrous gas; as it is known that the former has a great capacity for light, and the latter cannot be formed without its presence." As the velocity of light is 900,000 times greater than that of sound, it does not appear unreasonable to explain, in this way, its effects on the vibrations which proceed from sonorous bodies.

J. M.

\section{THE NATIONAL ACADEMY OF SCIENCES.}

As the meeting held on the 16 th of November last, and those of the three following days, were devoted to the reading of scientific papers only, little executive business was transacted and no new members. were elected.

At the meeting of the Council the following deaths of members were announced:

J. Homer Lane, of Washington, in May. S. S. Haldeman, of Chickies, Pa., in September, and Count L.S. Portalès, of Cambridge, Mass., in October.

The decease of Professor Benjamin Peirce, of Harvard College, one of the original active members of the Academy,but whose connection with it had been severed. was also announced.

Resolutions, thanking the Trustees of Columbia College for providing rooms for the meeting, and to President Barnard and officers of the college and other members of the Academy in New York for liberal entertainment of its members, were adopted.

THE FOLIOWING PAPERS WERE PRESENTED:

1. On the Basin of the Gulf of Mexico.-J. E. Hilgard.

2. On the Origin of the Coral Reets of the Yucstan and Florida Banks.-Alexander Agassiz.

3. Observations on Ice and Icebergs in the Polar Regions.-F. Schivatka.

4. On the Duration of the Arctic Winter. -F. Schwatka. 5. Mineralogical Notes.-Benjamin Silliman.

6. The Relationship of the Carboniferous Euphoberia to living and extinct Myriapods. - Samuel H. Scudder.

7. Report on the Dredging Cruise of the U. S. Steamer Blake, Commander Bartlett, during the Summer of 1880.- Alexander Agassiz.

8. On Some Recent Experiments in Determining the

Electro Motive Force of the Brush Dynamo-electric Lamps operating by Incandescence.-Henry Morton.

9. On the Intimate Structure of certain Mineral Veins. -Benjamin Silliman.

10. On the Ellipticity of the Earth as Deduced from

Pendulum Experiments.-C. S. Peirce.
11. On an Improvement in the Sprengel Air Pump.O. N. Rood.

12. On the Thermal Balance.-S. P. Langley.

13. On the Measurment of Radiant Energy.-S. P. Langley.

14. Causes which Determine the Progressive Movements of Storms. - Elias Loomis.

15. On the Antimony Mines of Southern Utah.-J.S. Newberry.

16. On the Conglomerate Ore Deposits of the United States and Mexico.-J. S. Newberry.

17. On Photographing the Nebula in Orion.-Henry Draper.

18. On Condensers for Currents of High Potential.-George F. Barker.

19. On Sigsbee's Gravitating Trap.-Alexander Agassiz.

20. On the Deposits of Crystalline Iron Ores of Utah. -J. S. Newberry.

21. On the Origin of Anthracite.-T. Sterry Ilunt.

22. On the Star-List of Abul Hassan.-C. II. F. Peters.

23. Dimensions of the Brain and Spinal Cord in some extinct Reptiles.- O. C. Marsh.

24. On the Rimravida..-E. D. Cope.

25. On the Miocene Canida.-E. D. Cope.

26. On a New General Method in Analysis.-Wolcott Gibbs.

27. Note on the Relations of the Oneonta and Mortrose Sandstones with the Sandstones of the Catskill Mountains.-James Hall.

\section{ON THE MEASUREMENT OF RADIINT ENERGY.*}

By Prof. S. P. Langley.

Sir IVilliam Herschel showed that a thermometer indicated more heat beyond the darkest red of the spectrum of a prism than in the brightest part of the color; therefore, he concluded thai light and heat were essentially different things. This view has apparently been confirmed by numerous other European experiments, and has been set forth in all but the most recent text-books. where different curves are drawn to exhibit the light and the heat of the sun. Of late years many leading minds have recognized that these were only different manifestations of radiant energy. Prominent ameng these is Dr. John IV. Draper, who asserted this principle long ago, and who has always maintained that if the heat in a pure diffraction spectrum could be accurately measured. its distribution would be found almost illentical with that of light. This was an experıment, which, however, could never have been satistactorily performed had it not been for the skill of Lewis M. Rutherfurd, Esq., of this city, who has made at his private expense the exquisitely delicate apparatus which can produce pure spectra, with a success far greater than any attained by the most skillful professional artisans of Europe.

By the use of one of these "gratings," made on Mr. Rutherford's engine by Chapman, and the emplojment of the thermal balance described in another paper, 1 succeeded in obtaining for the first time full and exact measurements of the distribution of energy in a pure spectrum, where no lens or prism had been used, and of fixing its relative amount, as determined accurately by the wave-lengths of light in all parts of the visible spectrum and in the ulira red. It remained to make some minute corrections for the selective absorbtions of the reflecting apparatus employed. The essential result, however, is of high theoretical interest; it is, that heat and light as received from the sun are now experimentally proved, so far as such measurements can prove it, to be in essence the same thing. The old delineations of

- Read befure the National Academy of Sciences, N. Y., 1880. 